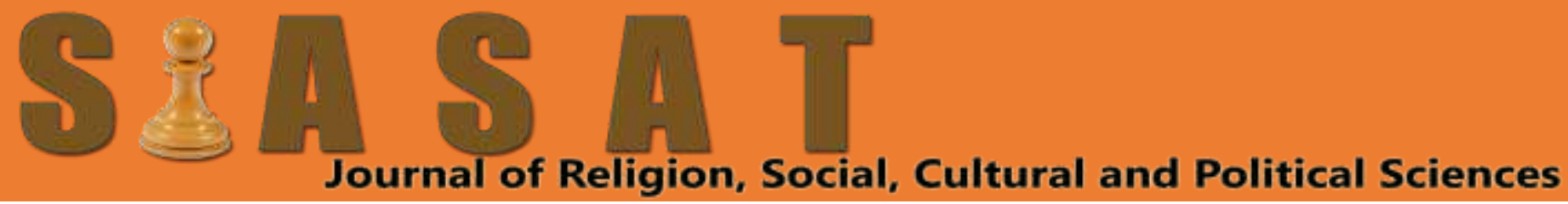

\title{
Is There Material Liability of Workers and Employees as a Type of Legal Liability in Contemporary Russian Law and Legislation?
}

\author{
Vladimir Valentinovich Kozhevnikov \\ Department of Theory and History of State and Law, Omsk State University Dostoevsky, Omsk, Russia \\ kta6973@rambler.ru
}

\section{Abstract}

The subject of this article is the social relations regulated by the legal institution of material responsibility of workers and employees. The purpose of the article is the argumentation of the position according to which material liability does not have the status of legal liability. To achieve this goal, the following tasks were implemented: 1) the positions of the overwhelming number of supporters - theorists of law and scientists of labor law - were considered - recognition of material responsibility as one of the types of legal responsibility, along with criminal law, administrative law, etc., which is interpreted as compensation for harm caused to a worker or employee to an enterprise (organization, institution): 2) the views of scientists (Anatoly Borisovich Vengerov, Mikhail Mikhailovich Rassolov, Magomed Imranovich Abdulaev), who do not recognize material responsibility as a type of legal responsibility, have been analyzed; 3) analyzed approaches to understanding legal responsibility; 4) the author's position of understanding legal responsibility and its signs is given, focusing on such as the onset of negative consequences, imposing new additional duties on the offender; 5) the problem of correlation of legal liability measures and protection measures is considered. In conclusion, it is concluded that the identification of measures of legal responsibility and measures of protection have led, first, to an incorrect definition of civil liability, with which material liability is often compared; secondly, the controversial allocation of both the legal function of legal responsibility and material responsibility as a kind of legal responsibility, which, despite its consolidation in labor legislation, in our opinion, in its essential and substantive characteristics refers to protection measures. The scientific article also emphasizes that the problem of distinguishing between legal liability and protection measures is extremely important for law enforcement entities, who must adequately understand what measures of state-legal coercion they apply, which thereby realize their goals. At the same time, they should keep in mind that in practice the named types of state legal coercion are often applied simultaneously (for example, a civil suit in criminal proceedings).

\author{
Keywords
}

material liability, legal liability,

protection measures, civil liability

\section{Introduction}

It seems that among the many urgent and interrelated problems of legal responsibility (its concept, signs, factual and legal grounds, the moment of its origin, etc.), which occupies an important place in the conceptual and categorical apparatus of the general theory of law, attention should also be paid to the problem of types legal responsibility in terms of industry. It is quite clear that, judging by the title of the scientific article, we are primarily interested in the so-called "material responsibility of workers and employees." 


\section{Research Methods}

When preparing a scientific article, the following methods were used:

\section{General Phillosophical (Dialectical-Materialistic)}

General philosophical (dialectical-materialistic) which is used in all social sciences:

1. General scientific (analysis and synthesis, logical and historical, comparisons, abstractions, etc.), which are used not only by the theory of state and law, but also by other social sciences;

2. Special methods (philological, cybernetic, psychological, etc.), developed by special sciences and widely used for the knowledge of state and legal phenomena;

3. Private scientific (formal legal, interpretation of law, etc.), which are developed by the theory of state and law.

\section{Results and Discussion}

\subsection{Supporters of Material Liability as a Type of Legal Liability}

We note that in the legal literature on the theory of state and law, which remains at present the most important legal science, which has an important, methodological significance in relation to branch legal sciences [1], among various types of legal liability (criminal, administrative, civil and etc.) the overwhelming number of modern theoretical scientists, apparently, without much hesitation, allocate material responsibility. For example, Viktor Lavrenievich Kulapov and Alexander Vasilyevich Malko argue in a laconic form that "financial liability follows for damage caused to an enterprise, institution, organization by workers and employees in the performance of their work duties" [2]. Roman Mikhailovich Romanov also admits material liability regulated by labor legislation, who specifies that the first is, as a rule, limited: the violator is responsible within the limits of his monthly salary (Article 241 of the Labor Code of the Russian Federation): full material liability assumes that the damage is subject to compensation in full [3]. Dmitry Anatolyevich Lipinsky argues that material liability by its legal nature is close to civil liability, but has its own characteristics (provided for by the labor law; is exclusively property in nature; its subjects are participants in labor relations; as a general rule, it is limited), allowing consider it an independent type of legal responsibility [4]. Considering that the author above refers to the measures of civil liability as the compulsory performance of the corresponding obligation, compensation for damages, forfeit (fine, penalties), collection of interest for the use of other people's funds, compensation for moral damage, etc. [4], such a statement is, in our view, erroneous and illogical. Equally, one should critically assess the position of Rosalina Vasilyevna Shagieva and Alexander Pavlovich Sevryukov, who, unreasonably linking civil liability with compensation for damage, restoration of violated rights, and other legal sanctions, believe that "the peculiarity of material and civil liability is that property and other damage can be compensated by the inflictor voluntarily ... "[5]. Vladik Sumbatovich Nersesyants at one time quite unreasonably argued that "the material responsibility of an employee is by its nature a special kind of civil liability for harm" [6]. A similar position is defended by Ivan Vladimirovich Timoshenko, saying that "material liability by its legal nature is still a kind of civil liability for harm," while specifying that "its specificity lies in the fact that between the subject of the offense (employee) and the victim party (enterprise, institution or organization) there is a special type of legal relationship-labor "[7]. Maria Pavlovna Avdeenkova, defining material liability as a "classical form of legal liability", argues that 
the former arises from labor relations, but it is based on the fact that material damage is caused by an employee to an employer or an employer to an employee. Considering that in this case the guilty person has an obligation to compensate for the harm caused, according to the author, this form of liability is close to civil law, and it always has a material character [8].

From the position of Vladimir Ivanovich Chervonyuk, from property liability in civil law "the employee's material responsibility is distinguished by the fact that the employee is responsible only for direct damage; lost income is not collected from him, as is typical for civil law "[9]. This point of view corresponds to the views of Timofei Nikolaevich Radko, who asserts that "the material responsibility of workers and employees differs from civil law (property liability under civil law) in that it is established within the framework of labor relations (that is, it has other grounds than property and occurs regardless of whether the employee is brought to disciplinary responsibility "[10].

The point of view of Vasily Ivanovich Vlasov and Galina Borisovna is objectionable. Vlasova, who, according to the industry principle (hereinafter, it is highlighted by us-VK), distinguish such types of retrospective legal responsibility as constitutional, administrative, civil, disciplinary, material and criminal [11].

With regard to the problem of types of legal liability, the position of Valery Nikolaevich Protasov and Natalya Valerievna Protasova, who believe that the traditional classification of legal liability is based on a non-branch feature (as other scientists, Vladimir Valentinovich Kozhevnikov, as a rule, believe) is of undoubted interest, since the division of branches into the system of law occurs by the nature of regulatory norms, and responsibility is directly related to protective norms, which are of a different nature and operate according to their own laws [12].

From the standpoint of Anatoly Stepanovich Shaburov, material liability is the most widespread type of legal liability, for "in the criminal legislation, it acts as a confiscation; in civil - in the form of compensation for material damage, compensation for moral damage, payment of a forfeit, interest, etc .; in labor law, in the form of an employee's responsibility for causing material damage to his enterprise or employer for delayed payment of wages, etc. "[13].

\subsection{Material Liability in the Science of Russian Labor Law}

It is quite natural that it is the material responsibility of workers and employees that is given attention in the science of labor law. So, Vladimir Maksimovich Lebedev and Tatyana Mikhailovna Fakhrutdinova, noting that labor legislation does not define material liability, but is there only a rule of law securing the obligation of a party to an employment contract to compensate for damage caused by it to the other party of this contract (Part 1 of Article 232 Labor Code of the Russian Federation), believe that the first occurs for damage caused by a party to the employment contract as a result of culpable illegal behavior (action or inaction), unless otherwise provided by law (Article 233 of the Labor Code of the Russian Federation). From the point of view of the authors, culpable illegal behavior in the labor process is a labor offense, which, in our opinion, is very unreasonably identified with a disciplinary offense [14]. Yulia Vladimirovna Zhiltsova interprets material liability as "... the obligation of one party to the employment contract to compensate for the damage caused by it to the other party as a result of guilty unlawful behavior, in the amount and in the manner prescribed by labor legislation" [15].

A number of provisions concerning the material responsibility of the employee were expressed by Yulia Pavlovna Svit. So, in her opinion, recognizing that material responsibility comes for committing an offense in the field of labor law, he emphasizes 
that ".. in this case, we are not talking about responsibility for the very fact of committing an offense, but for the occurrence of property consequences as a result - damage to the employer ; the purpose of bringing to financial responsibility is not only to "punish" the employee, but also to at least partially compensate the harm caused to the employer". The author draws attention, firstly, that the material liability of an employee is considered in the legislation as liability arising from improper performance or non-performance of an employment contract; secondly, like some other authors, whose position was analyzed above, that the property nature of this type of legal liability, as well as the fact that it arises in connection with non-fulfillment or improper fulfillment of contractual obligations, predetermines some of its similarity with civil liability [sixteen].

Yuri Nikolaevich Poletaev, recognizing material liability as an independent type of legal liability, which is mainly characteristic of relations regulated by labor law, is convinced that the first is the obligation of the employee to compensate the employee in the manner and amount of property damage caused by his fault to the enterprise in which it works [17]. It is interesting to note, and this is of fundamental nature, that earlier the author interpreted the concept of legal responsibility in a completely different way: as "a measure of state coercion, which is expressed in negative consequences for the offender, which come in the form of personal or property restrictions" [17].

Commentators of the Labor Code of the Russian Federation, speaking of material responsibility in general, pointing out that "the implementation of the mutual rights and obligations of the parties to the employment contract is ensured (in case of violation) by measures of responsibility", emphasize that the first is provided for by Art. 232 of the Code and "is a bilateral internal responsibility of the parties to an existing employment contract (as opposed to other types of responsibility)" [18]. In relation to Art. 238 "Liability of an employee for damage caused to the employer" of this Code states that this type of liability is "in compensation by the employee of the property damage that he caused to the employer." At the same time, it is clarified that the employee is obliged to compensate the employer for direct actual damage caused to him (for example, shortage and damage of materials and valuables, expenses for repairing damaged property, etc.), which means: a) a real decrease or deterioration of the employer's cash assets; b) the need to incur expenses for the acquisition (restoration) of property or excessive payments [18].

\subsection{Opponents of Allocating Material Liability as a Kind of Legal Liability}

For the sake of fairness, we note that the analysis of legal literature on the general theory of law clearly enough shows that not all theoretical scientists in the system of legal responsibility allocate material responsibility [19]. For example, Anatoly Borisovich Vengerov analyzed only criminal, administrative-legal, disciplinary, civil (tort) [20]. Mikhail Mikhailovich Rassolov believes that "in the legislation, based on the nature and degree of social harm of offenses, the following types of legal liability are provided: disciplinary, administrative, civil and criminal", drawing attention to the fact that "some theorists of state and law also single out constitutional ( responsibility for violation of articles and provisions of the Constitution of the Russian Federation) and statutory responsibility (this is the responsibility of subjects determined by their legal status) "[21]. Depending on the nature of the offense, Magomed Imranovich Abdulaev distinguishes criminal, administrative, disciplinary, civil and constitutional liability [22]. Showing a certain inconsistency in this regard, Vladimir Ivanovich Chervonyuk focuses on the characteristics of only civil, criminal, administrative and disciplinary responsibility [23].

It seems that those scientists are absolutely right who do not single out material liability as a kind of legal liability, denying its status as such. 


\subsection{About the Concept of Legal Responsibility}

In support of this, to some extent categorical statement, a number of reasons should be given. First of all, it should be defined with the concept of "legal responsibility".

We believe that, despite the different interpretations of the concept of legal responsibility [24; 25], they can be classified as follows.

The first group consists of those scientists who understand the latter as a measure of state coercion for a committed offense associated with the perpetrators suffering personal (organizational) or property privations. [26]. True, some scholars at the same time argue that legal responsibility is used to restore the broken order and (or) punish the person who committed the offense [27].

Oleg Ernestovich Leist, relying on the fact that there is a close connection between legal duty and responsibility, questioned the assertion that responsibility always means the onset of adverse consequences for the offender [28]. Marina Vladimirovna Zadneprovskaya believes that legal responsibility is a measure of state coercion provided for by law, expressing the condemnation and punishment of a subject for an offense committed by him [29].

Lydia Aleksandrovna Nikolaeva writes that legal responsibility is those legal consequences, deprivations, restrictions that occur for a person in case of violation of a legal norm [30]. Anatoly Borisovich Vengerov defined legal responsibility as a measure of influence on the offender, established by law, containing adverse consequences for him, applied by state bodies in the manner also established by the state [20].

The second group is united by those scientists who define legal responsibility as the obligation of the subject of the law, provided for by legal norms, to endure the consequences of an offense that are unfavorable for him.

Scientists emphasize that legal responsibility is a complex social and legal phenomenon. It includes at least two parties: the state and the offender. A law enforcement relationship develops between them, in which the state, represented by its competent authorities, acts as an authorized party, and the offender as an obligated party. At the same time, it is noted that both the entitled and the obligated parties act within the framework of the law and the implementation of legal responsibility is carried out on the basis of law, specific sanctions, legal norms providing for liability specifically for this offense [31]. A similar point of view was expressed by Sergei Nikitovich Kozhevnikov [32], Ivan Nikolaevich Senyakin [33], as well as the Soviet theoretical scientist Viktor A. Alekseevich Kozlov [34]. This approach served as the basis for considering responsibility in two aspects: "positive" - promising (for future actions) and retrospective, i.e. traditional (for actions already committed). The scientist confidently says that these approaches have the right to exist, since they reflect real social processes in the field of legal regulation. The author emphasizes that one cannot disagree with the fact that being responsible means foreseeing the consequences of one's actions, trying them on to social ones, including legal norms, acting in society. Sergey Nikitovich Kozhevnikov believes that these aspects of legal responsibility are dialectically interrelated and inseparable from each other [32].

In general, he agrees with the opinion of Tatyana Dmitrievna Zrazhevskaya, who argues that an exclusively retrospective approach cannot fully reveal the role of legal responsibility and therefore a promising aspect should be considered as a legal one [38]. Irresponsibility and impunity breed new abuses and crimes, undermine law and order, destabilize society, and corrupt people. Even Charles Louis Montesquieu remarked: "Look into the reasons for all licentiousness and you will see that it stems from impunity" [39].

As for our position on the understanding of legal responsibility, its essence is as follows. First, it should be noted that legal responsibility is a form of social responsibility. 
The latter arises when a person's behavior has social significance and is governed by appropriate social norms. In addition to legal responsibility, there are other forms of social responsibility: moral, political, organizational (corporate), party and professional.

Social responsibility can be viewed from the point of view of two aspects: 1) positive (perspective), which is associated with duty, a responsible attitude to business and 2) retrospective, which arises from the behavior of the subject in the past.

Secondly, considering legal liability only as retrospective, we believe that the first should be understood as follows: this is the application to the offender of the measures of state coercion provided for by the penalty (punitive) sanction of the legal norm, expressed in the form of personal, property or organizational deprivation.

We believe that the signs of legal responsibility are as follows: 1) it is inextricably linked with state-legal coercion; 2) combined with state condemnation and public censure of the behavior of the offender; 3) is associated with the infliction of adverse personal, property or organizational consequences on the offender; 4) is embodied in a procedural form in the course of law enforcement activities of the competent authorities of the state; 5) the establishment of the nature and volume is determined by the penalty (punitive) sanction of a legal norm.

When characterizing legal liability, the authors quite reasonably draw attention to such a feature of it, according to which it "entails negative consequences (imprisonment, parental rights), imposing new additional obligations on it (payment of a certain amount, performing any actions)" [40].

\subsection{Measures of Legal Responsibility and Measures of Protection: The Problem of Correlation}

It seems to be extremely important in the context of the problem under consideration to understand that legal responsibility is only one of the forms (types) of state legal coercion, which exists along with other types, including protection measures (legal remedies), which are associated with the use of legal sanctions and are aimed at protecting subjective rights (for example, enforced debt collection, enforced recovery of child support, reinstatement of an illegally dismissed employee at work, etc.).

According to Andrey Ivanovich Kaplunov, coercive measures are methods, techniques, means and actions established by law that make it possible to force a person to fulfill legal obligations and comply with legal prohibitions, or these are additional encumbrances in connection with the commission of unlawful acts by a person, the use of which ensures the prevention and suppression of offenses, bringing the perpetrators to justice, restoring violated subjective rights, protecting the individual and her property from a source of danger [41]. In another work, the scientist again distinguishing between legal responsibility and legal restoration, the latter form of state coercion is characterized as follows: it acts as a way to protect the subjective rights of individuals and legal entities and provides an equivalent restoration of violated subjective rights. At the same time, attention is drawn to the fact that the remedial measures included in this legal form of state coercion are compulsory actions used in cases of non-fulfillment of legal obligations, violation of subjective rights, and their main purpose is the restoration of normal ties and relations, restoration of violated subjective rights [42].

As noted by scientists, "the purpose of protection measures is to restore the previous normal legal status by forcing the subject to fulfill a previously imposed but not fulfilled legal obligation. Additional negative consequences for the subject who committed ... the unlawful act may occur, but they are not basic, but concomitant"[12]. The well-known Russian scientist Sergei Sergeevich Alekseev, interpreting the protection of law as state- 
compulsory activity aimed at the implementation of "restorative" tasks - to restore the violated right, to ensure the fulfillment of a legal obligation, noted the following: "if the main function of legal responsibility is a penalty (the guilty person answer "), then the function of protection measures is reduced to restorative tasks, to ensure the fulfillment of a legal obligation, protection of the right" [43].

Alexey Alekseevich Ivanov in his monograph emphasizes that "legal responsibility is, to a large extent, a punishment for an offense" [44]. It should be agreed that protection measures differ from legal liability in that they come for an offense that often has a minimum degree of public danger (or rather, public harm - Vladimir Valentinovich Kozhevnikov), or an act that is a "legal anomaly", minor deviations from normal law and order, not acquiring the nature of offenses. The measures of protection consist in the fact that the person is forced to fulfill the obligation lying on him, which he should have previously performed, but did not fulfill, however, additional deprivations (in addition to fulfilling the obligation) in this case do not occur for the person [45].

It seems that here it is very appropriate to cite the warning of Anatoly Borisovich Vengerov, who wrote that "measures of legal responsibility should not be confused with other measures (including measures of protection - Vladimir Valentinovich Kozhevnikov), which can also be coercive and outwardly very are similar to measures of legal responsibility, but have a completely different purpose "[20]. Nikolai Andreevich Pyanov, highlighting the protection measures associated with the application of a number of legal sanctions and aimed at protecting violated subjective rights, at the same time considered material liability as a mutual obligation to compensate the parties to the labor contract for damage. At the same time, the author noted that "some researchers do not single out protection measures as an independent type of state coercion, but consider them to be a certain type of legal liability measures" [46]

Valery Vasilievich Lazarev, stating that sometimes protection measures are identified (and, unreasonably, Vladimir Valentinovich Kozhevnikov) with measures of legal responsibility. From the position of the author, there are certain grounds for this, because protection measures can also be applied as a reaction to a committed offense instead of measures of legal responsibility (for example, the collection of sums of money from the debtor due to non-performance of the loan agreement, that is, for a civil offense) [47] ...

Rudolf Konstantinovich Rusinov, noting the coherence, the similarity of protection measures and legal responsibility, drew attention to the fact that the first "are provided for by the sanctions of legal norms, but by the sanctions of a legal nature; are designed to ensure, guarantee the normal operation of the legal regulation mechanism"[48]. However, in spite of the above provisions, in the legal literature, scholars confuse measures of legal responsibility and measures of protection, while showing inconsistency, contradictory and illogical. For example, Vladimir Mikhailovich Baranov, and it is necessary to agree with this, first arguing that "legal responsibility is always a certain type of legal deprivation, encumbrance, damage", which presupposes "restrictions of a personal, organizational or property nature," which changes "downwardly its legal status (restriction of freedom, derogation of dignity, material costs ", nevertheless, below highlights the material responsibility of employees of both state and private enterprises (organizations) [49]. 


\subsection{Consequences of Mixing Legall Liability and Protection Measures}

As a consequence of the mixture of legal liability and protection measures, which in the literature has a massive character, the authors, firstly, unreasonably single out penal or punitive liability, and legal liability, which appears mainly in the form of civil law [50]. Oleg Ernestovich Leist, distinguishing between punitive and legal responsibility, at one time wrote that the first is used for crimes or administrative or disciplinary offenses, and the second is the restoration of illegally violated rights in the compulsory execution of an unfulfilled duty [51]. A similar view is defended by a number of other legal scholars [52; 53; 54]. In the same row is the point of view of Nikolai Alekseevich Dukhno and Viktor Ivanovich Ivakin, who, according to the methods of influence, distinguish compensatory liability aimed at compensation for harm (the obligation to compensate for the harm caused by the norms of civil and administrative law), and repressive, which includes administrative, criminal, disciplinary responsibility [55].

Secondly, a very controversial interpretation of civil liability, which is often correlated with material liability, paying attention to their similarities and differences. For example, Elena Leonidovna Kovaleva believes that "this type of liability is primarily compensatory in nature and aims to fully compensate for the damage caused by the illegal actions of the offender"; "At the same time, civil liability provides for punitive sanctions: fines, penalties, forfeit" [53].

Speaking about civil liability, Anatoly Stenanovich Shaburov argues that "it is predominantly of a restorative nature, but involves deprivation of a penalty, property order in the form of a fine, fine, payment of arrears, etc." [13]. From the position of Vladimir Mikhailovich Baranov, "civil liability is expressed in damages, forfeit, fines, penalties, forced restoration of the past legal status, compulsory execution of a legal obligation" [49]. Mikhail Nikolaevich Marchenko, among the sanctions applied for certain civil offenses, calls: "compensation for damages, collection of a penalty, compensation for moral harm, etc." [50]. Boris Ivanovich Puginsky and Dinus Nurimanovich Safiullin emphasize that "liability in civil and commercial legislation ... is provided for in the form of a general obligation of the debtor to compensate for losses caused by non-performance, improper performance of an obligation or damage" [56].

Describing civil liability, Timofey Nikolayevich Radko, Valery Vasilyevich Lazarev and Lyudmila Aleksandrovna Morozova, quite unreasonably call it compensatory liability, "when one of the parties is compensated for the losses it has incurred"; restorative, "since through this type of responsibility violated rights are often restored, the previous legal status of the subjects is restored (for example, invalidation of the transaction returns the parties to their original financial position" [57].

In our opinion, civil liability is provided for the commission of civil offenses (tort), that is, causing property damage to citizens or organizations with which the offender is not in labor relations.

There are two types of civil liability: a) contractual, which occurs as a result of nonperformance or improper performance of obligations under the contract and, in addition to the law, can also be provided for by the contract and b) non-contractual, which occurs in the event of harm caused by a person who is not in a contractual relationship with the victim, and provided only by law.

One of the common means of civil liability is the collection of a penalty. According to paragraph 1 of Art. 330 of the Civil Code of the Russian Federation, "a forfeit (fine, penalty) is a sum of money determined by law or contract, which the debtor is obliged to pay to the creditor in the event of non-fulfillment or improper fulfillment of an obligation, in particular in case of delay in fulfillment." 
Third, there is also a very unjustified position of the overwhelming number of legal scholars, according to which they consider the restorative function of legal responsibility [58]. Note that, in our opinion, legal responsibility implements punitive (penalty), preventive and educational functions; at the same time, we do not recognize the restorative function characteristic only of protective measures.

Fourth, the unjustified allocation of material liability as an independent type of legal liability, which, in our opinion, by its essential and substantial characteristics refers to protection measures.

\section{Conclusion}

In conclusion of this article, I would like to draw your attention to the following circumstances. Firstly, we admit objections from possible opponents who defend the existence of material legal liability on the grounds that the latter is enshrined in the relevant articles of the Labor Code of the Russian Federation. However, while recognizing the importance and necessity of studying general theoretical problems, referring to certain regulatory legal acts, it should be recognized that they often do not correspond to the true, and not distorted theory of law, which some authors admit. For example, in the Constitution of the Russian Federation of the new edition of 2020, part 1 of Art. 1 Russia is declared a legal state in the absence of the necessary, from the point of view of the theory of law, signs and prerequisites, including its satellite, civil society. It seems that the given rule of law can be an example of a violation of such a methodological principle of cognition of state-legal phenomena as objectivity, which implies the need to see the state, law, state-legal phenomena as they really are.

Until recently, for more than 25 years, in Chapter 7 of the Constitution of the Russian Federation "Judicial Power" took place for some unknown reason, Art. 129, dedicated to the prosecutor's office. At the same time, and during the existence of this article in the corresponding chapter of the Basic Law of the country, scientists drew attention to the fact that the prosecutor's office has a different legal nature and functional purpose than the judicial authorities. It was stated categorically that "in fact, the prosecutor's office is outside the system of the judiciary; it should not be confused and even more so identified with the aforementioned power, considered as one of the institutions, instruments of the judiciary "[59]. Commentators of the country's Basic Law wrote that "although the article being commented on is included in the chapter" Judicial Power", this does not make the prosecutor's office a subject of this particular power, insofar as such, in accordance with Art. 118 of the Constitution can only be a court "[60].

The Russian legislator in paragraph 1 of Art. 22 of the Civil Code of the Russian Federation enshrined that "no one can be limited in legal capacity and legal capacity otherwise than in cases and in the manner prescribed by law," although in relation to the legal capacity of an individual, the position has long been strengthened according to which it is inseparable from the person, i.e. That is, you cannot deprive a person of legal capacity, take away or limit it. In other words, it should be about limiting only the legal capacity of an individual [61].

Secondly, we believe that the problem of distinguishing between legal liability and protection measures is extremely important for law enforcement entities, who must adequately understand what measures of state-legal coercion they apply, which thereby realize their goals. At the same time, they should keep in mind that in practice the named types of state legal coercion are often applied simultaneously (for example, a civil suit in criminal proceedings). 


\section{References}

[1]. Kozhevnikov V. V. Status of the modern general theory of state and law in the system of legal sciences // Budapesh International Institute of Research and Criticism. 2020.Vol. 3. No.2. Pp.738-746.

[2]. Kulapov Victor Lavrenievich, Malko Alexander Vasilievich. Theory of state and law: textbook. M.: Norma, 2009.P. 327.

[3]. Romanov Roman Mikhailovich. Legal responsibility // Theory of state and law: textbook / under total. ed. Orest Vladimirovich Martyshina. M.: Norma, 2007. P. 406.

[4]. Lipinsky Dmitry Anatolyevich. Legal responsibility // Theory of state and law: textbook / otv. ed. Alexander Vasilyevich Malko. M.: KNORUS, 2008.P. 288.

[5]. Shagieva Rosalina Vasilievna, Sevryukov Alexander Pavlovich. Behavior of people in the legal sphere // Actual problems of the theory of state and law: textbook / otv. ed. Rosalina Vasilievna Shagieva. M.: Norma, 2011. Pp. 482-483.

[6]. Nersesyants Vladik Sumbatovich. General theory of law and state: textbook. M.: Norma, 2002.P. 526.

[7]. Timoshenko Ivan Vladimirovich. Legal responsibility // Lyubashits Valentin Yakovlevich, Mordovtsev Andrey Yurievich, Timoshenko Ivan Vladimirovich, Shapsugov Damir Yusufovich. Theory of state and law: textbook. M .: ICC "Mart", 2003. Pp. 590-591.

[8]. Avdeenkova Maria Pavlovna. The system of legal responsibility in modern Russia // State and law. 2007, No. 7, p. 29.

[9]. Chervonyuk Vladimir Ivanovich. Theory of state and law: textbook. M.: INFRA-M, 2006.P. 575.

[10]. Radko Timofey Nikolaevich. Theory of state and law: textbook. Moscow: Academic Project, 2005. P.720.

[11]. Vlasov Vasily Ivanovich, Vlasova Galina Borisovna. Theory of state and law: textbook. Rostov n / a: Phoenix, 2011. P.287.

[12]. Protasov Valery Nikolaevich, Protasova Natalia Valerievna. Lectures on general theory of law and theory of the state. Moscow: Ed. House "Gorodets", 2010. Pp. 415, 418.

[13]. Shaburov Anatoly Stepanovich. Lawful Conduct. Offense. Legal responsibility // Theory of state and law: textbook / otv. ed. Victor Dmitrievich Perevalov. M.: Norma, 2007.Pp. 271, 272.

[14]. Lebedev Vladimir Maksimovich, Fakhrutdinova Tatiana Mikhailovna. Material responsibility of the parties to the employment contract // Labor law: textbook / ed. Vladimir Maksimovich Lebedev. M.: Norma, 2011.P. 243.

[15]. Zhiltsova Yulia Vladimirovna. Material liability of the parties to the contract // Labor law of Russia: textbook / ed. Svetlana Yurievna Golovina, Mstislav Viktorovich Molodtsov. M.: Norma, 2010. P. 455.

[16]. Sweet Julia Pavlovna. Material responsibility of the employee // Labor law. 2004, No. 9. P. 74.

[17]. Poletaev Yuri Nikolaevich. Some legal problems of responsibility in labor law // Labor law. 2001. No. 1. P.32.

[18]. Comment on the Labor Code of the Russian Federation / otv. ed. Yuri Petrovich Orlovsky.- M.: INFRA-M-KONTRAKT, 2008.Pp. 751, 762-763.

[19]. Lazarev Valery Vasilievich, Lipen Sergey Vasilievich. Theory of state and law: textbook. M.: Yurayt, 2010.P. 524. 
[20] Vengerov Anatoly Borisovich. Theory of state and law: textbook. M.: Omega-L, 2007. Pp. 544-545, 544-547.

[21]. Rassolov Mikhail Mikhailovich. Problems of the theory of state and law: textbook. M.: UNITY-DANA, Law and Law, 2007.P.329.

[22]. Abdulaev Magomed Imranovich. Theory of state and law: textbook. M.: Economics 2006. P. 499.

[23]. Chervonyuk Vladimir Ivanovich. Offense and legal responsibility // General theory of law and state: textbook / ed. Valery Vasilyevich Lazarev. M.: Norma, 2010. Pp. 352357.

[24]. Kozhevnikov Vladimir Valentinovich. On the problems of the concept of legal responsibility: general theoretical aspect // Modern law. 2018. No. 12. S.5-9.

[25]. Kozhevnikov Vladimir Valentinovich. On the problem of the theory of legal responsibility // Bulletin of the Tomsk state. University. Right. 2018.No. 28. Pp.5-19.

26]. Social science: textbook / otv. ed. Mikhail Nikolaevich Marchenko. M .: Zertsalo, 1999. P. 330.

[27]. Leist Oleg Ernestovich. Methodological problems of legal responsibility // Problems of the theory of state and law: textbook / ed. Mikhail Nikolaevich Marchenko. - M .: Jurist. Pp. 625, 626.

[28]. Leist Oleg Ernestovich. Sanctions in Soviet law M.: Gosyuridizdat, 1962. Pp.47-48.

[29]. Theory of state and law: textbook. / ed. Pavel Viktorovich Anisimov. M .: IMTs GUK Ministry of Internal Affairs of Russia, 2005.S. 162.

[30]. State discipline and responsibility / ed. Lyudmila Ivanovna Antonova, Boris Ivanovich Kozhokhin. L.: Publishing house of Leningrad State University, 1990.Pp. 50, 50-51.

[31]. Khropanyuk Valentin Nikolaevich. Theory of state and law: textbook. M :. IPP "Fatherland", 1993. P.242.

[32]. Kozhevnikov Sergey Nikitich. Legal responsibility // General theory of law: a course of lectures / ed. Vladimir Konstantinovich Babaev. Nizhny Novgorod: Nizhny Novgorod High School of the Ministry of Internal Affairs of Russia, 1993. Pp. 456457, 467.

[33]. Senyakin Ivan Nikolaevich. Concept, signs and types of legal responsibility // Theory of state and law: a course of lectures / ed. Nikolai Ignatovich Matuzov, Alexander Vasilyevich Malko), Moscow: Yurist. P. 599.

[34]. Theory of state and law: textbook. / ed. Alexei Ivanovich Korolev, Lev Samoilovich Yavich. L .: Leningrad Publishing House. un-that. P.521.

[35]. Protasov Valery Nikolaevich. Theory of state and law: textbook. M.: Yurayt, 2004.P. 158.

[36] Brother Sergei Nikitich. Legal responsibility and legality (Outline of the theory) M.: Jurid. liter, 1976. P. 85.

[37]. Theory of state and law: textbook. / ed. Vladimir Konstantinovich Babaev, Moscow: Yurist, 1999. Pp. 506-507.

[38]. Zrazhevskaya Tatiana Dmitrievna. Responsibility for Soviet state law Voronezh: Voronezh University Publishing House, 1980. Pp.20-21.

[39]. Montesquieu Charles Louis. Elected. manuf. M.: Gospolitizdat, 1955.P. 233.

[40]. Vinichenko Oleg Yurievich, Popov Vladimir Ivanovich. Theory of state and law: textbook. M.: Prospect, 2010.P. 344.

[41]. Kaplunov Andrey Ivanovich. On the main features and concept of state coercion // State and Law. 2004. No. 12. P. 14. 
[42]. Kaplunov Andrey Ivanovich. On the classification of measures of state coercion // State and law. 2006. No 3.P.10.

[43]. Alekseev Sergei Sergeevich. General theory of law: textbook. M .: Prospect, 2008.Pp. 202-203.

[44]. Ivanov Alexey Alekseevich. From talion to individualization of legal responsibility. Historical sketch of the formation of the legal principle: monograph. M.: UNITYDAN, Law and Law, 2009. P.4.

[45]. Theory of law and state: textbook. / ed. Valery Vasilievich. Lazarev. M $\therefore$ New lawyer, 1997.P. 247.

[46]. Pyanov Nikolai Andreevich. Consulting on the theory of state and law: textbook. Irkutsk: Irkutsk State University, 2010. P. 487.

[47]. Lazarev Valery Vasilievich. Offense and legal responsibility // Problems of the general theory of law and state: textbook / under the general ed. Vladik Sumbatovich Nersesyants. M.: Norma: INFRA-M, 2010. P. 491.

[48]. Rusinov Rudolf Konstantinovich. Legal responsibility // Problems of the theory of state and law: textbook / ed. Sergei Sergeevich Alekseev. M.: Jurid. liter, 1987.P. 316.

[49]. Baranov Vladimir Mikhailovich. Legal responsibility // Theory of state and law: textbook / ed. Vladimir Konstantinovich Babaev. M.: Yurist, 2007. Pp. 544, 546, 550

[50] .Marchenko Mikhail Nikolaevich. Problems of the general theory of state and law in 2 volumes: textbook. M .: Prospect, 2008. Volume 2. Law. P.640

[51]. Leist Oleg Ernestovich. Offense and legal responsibility // Theory of state and law: textbook / ed. Mikhail Nikolaevich Marchenko. M.: Mirror. 2009.Pp. 828, 829.

[52]. Golovistikova Anastasia Nikolaevich, Dmitriev Yuri Albertovich. Problems of the theory of state and law: textbook. M .: Eksmo, 2005.P. 467.

[53]. Kovaleva Elena Leonidovna. Legally significant behavior, offenses, legal responsibility // Problems of the theory of state and law: textbook / ed. Vladimir Mikhailovich Syrykh. M .: Eksmo, 2008.P. 466

[54]. Boshno Svetlana Vladimirovna. Theory of state and law: textbook. M.: Eksmo, 2007. Pp.276-277.

[55]. Dukhno Nikolay Alekseevich, Ivakin Victor Ivanovich. Concept and types of legal responsibility // State and law. 2000. No 6. P. 15.

[56]. Puginsky Boris Ivanovich, Safiullin Dinus Nurimanovich. Legal Economy: Problems of Formation. M.: Jurid. liter, 1991.P. 187.

[57]. Radko Timofey Nikolaevich, Lazarev Valery Vasilievich, Morozova Lyudmila Aleksandrovna. Theory of state and law: textbook. M .: Prospect, 2012.P. 385.

[58]. Kozhevnikov Vladimir Valentinovich. Functions of legal responsibility: general theoretical and sectoral aspects // Modern law. 2015. No 4. P.5-14.

[59]. Baglai Marat Viktorovich, Gabrichidze Boris Nikolaevich. Constitutional law of the Russian Federation: textbook. M .: INFRA-M-KODEKS, 1996. P.425.

[60]. Scientific and practical commentary to the Constitution of the Russian Federation / otv. ed. Valery Vasilievich Lazarev. M.: Spark, 1997. P. 549.

[61]. Nechaeva Alexandra Matveevna. On the legal capacity and capacity of individuals // State and Law. 2001. No 2. P. 32. 